Journal of Applied Biology \& Biotechnology Vol. 5 (01), pp. 047-052, Jan-Feb, 2017

Available online at http://www.jabonline.in

DOI: $10.7324 / \mathrm{JABB} .2017 .50108$

(c) $\mathrm{BY}-\mathrm{NC}-\mathrm{SA}$

\title{
Klebsiella pneumoniae VRE36 as a PGPR isolated from Saccharum officinarum cultivar Co99004
}

\author{
Gurvesh Bhardwaj, Rushabh Shah, Bhrugesh Joshi, Prittesh Patel* \\ C G Bhakta Institute of Biotechnology, Uka Tarsadia University, Bardoli, 394350 - Gujarat, India.
}

\begin{tabular}{|c|c|}
\hline ARTICLE INFO & ABSTRACT \\
\hline $\begin{array}{l}\text { Article history: } \\
\text { Received on: } 17 / 08 / 2016 \\
\text { Revised on: } 20 / 09 / 2016 \\
\text { Accepted on: } 03 / 10 / 2016 \\
\text { Available online: } 20 / 01 / 2017\end{array}$ & $\begin{array}{l}\text { Klebsiella species known to exhibit important PGP traits like solubilization of phosphate, phytohormone } \\
\text { production and good germination potential. In present study, based on the Phosphate solubilization and IAA } \\
\text { production bacterial strain VRE36 was selected among the isolates collected from different sugarcane cultivar } \\
\text { rhizosphere growing near Bardoli area for characterization and molecular identification through 16S rRNA gene } \\
\text { sequence, which confirms the isolate as Klebsiella pneumoniae. The phosphate solubilization index of the isolate }\end{array}$ \\
\hline $\begin{array}{l}\text { Key words: } \\
\text { Klebsiella pneumoniae, } \\
\text { PGPR, Phosphate } \\
\text { solubization, Seed } \\
\text { germination, Sugarcane. }\end{array}$ & $\begin{array}{l}\text { recorded was } 3.9 \text { and quantitative estimation reveals } 17.4 \pm 1.78 \mu \mathrm{g} / \mathrm{ml} \text { release of phosphate in NBRIP broth. The } \\
\text { high amount of IAA produced was } 45.32 \pm 2.46 \mu \mathrm{g} / \mathrm{ml} \text { after } 96 \text { hour incubation at } 37{ }^{\circ} \mathrm{C} \text {. In seed germination assay } \\
\text { with } V \text { radiate, } C \text { tetragonoloba and } V \text { unguiculata, treatments with bacteria were supported good plant height, } \\
\text { dry weight and fresh weight when compared with controls. Maximum percentage of germination was recorded in } \\
V \text { radiate }(97.78 \% \text { ). The improved seedling parameters of the inoculated crop seeds indicated the potential of this } \\
\text { isolate to be used in a bio-fertilizer formulation for sustainable production. }\end{array}$ \\
\hline
\end{tabular}

\section{INTRODUCTION}

Plant growth-promoting rhizobacteria (PGPR) are the rhizosphere bacteria that can enhance plant growth by a wide variety of mechanisms like phosphate (P) solubilization, siderophore production, biological nitrogen fixation and Indole acetic acid (IAA) production [1]. The potentiality of PGPR in agriculture to achieve higher yields is steadily increased as it offers an attractive way to replace the use of chemical fertilizers, pesticides and other supplements. The dependence on chemical is associated with problems such as environmental pollution, health hazards, interruption of natural ecological nutrient cycling and destruction of biological communities that otherwise support crop production. Phosphorous is one of the major micronutrient require by the plant for growth. However, Continues application of phosphorous fertilizer may result in negative impacts soil in terms of accumulation due to its fixation and precipitation behaviour which lower the efficiency of added P. It has been reported that more than $80 \%$ of applied $\mathrm{P}$ in soil precipitates in the presence of metal ion complexes such as $\mathrm{Ca}^{2+}, \mathrm{Fe}^{3+}$ and $\mathrm{Al}^{3+}$ and remains in

\footnotetext{
* Corresponding Author

Email: pritteshpatel@gmail.com
}

soil in insoluble mineral form [2]. Furthermore the prices of $\mathrm{P}$ fertilizer raised several fold higher in last few years have made it most expensive and not-affordable to poor farmers. The introduction of PGPR with phosphate solubilization activity can be viable and sustainable option for the removal of unutilized insoluble phosphate from soil by making them available for plant. Investigation of modes of action of phosphate solubilising bacteria (PSB) are increasing at a rapid pace as efforts are made to exploit them commercially as biofertilizer [3]. Due to constant liberation of nutrients from plant roots, soil microbes are found to dominate the niche and their by helps in plant growth promotion under various mechanisms [4]. PSB had shown an effective role in growth promotion of plants by dissolving inorganic insoluble phosphate and converting the phosphorus in a form available to the plants [5]. Most PSB are highly specific to a host plant, and host-specificity in colonization is an important parameter for the preparation of biofertilizer [6]. However, some PSB have a rather wide host range. Pseudomonas sp. dominated in the rhizosphere of maize, soya bean, oat, and wheat, and Berkholderia sp. is being used as a biofertilizer in several important crops [7-10]. A single microbe can be used for several crops, especially when using a nonspecific genus like klebsiella. As sugarcane is a long duration crop and faces many biotic and abiotic stresses during growth phase, the PGPR found in sugarcane root zone may be potent and useful for application to other crops 
Keeping in mind the objectives of this study were (i) to isolate PGPR from sugarcane rhizosphere under in vitro conditions and to select the potent isolate on the basis of phosphate solubilization (ii) to analyse biochemical properties, antibiotic susceptibility, IAA production and $16 \mathrm{~S}$ rRNA sequence (iii) to assesses the PGP potency of isolate by seed germination assay in vivo on cereal crops in a pot experiment.

\section{MATERIAL AND METHODS}

\subsection{Bacterial strain isolation and screening}

A rhizospheric soil samples from sugarcane was used for the isolation of PGPR. Samples were added into a flask containing $90 \mathrm{ml} \mathrm{mL}$ sterile PBS and then made serial dilutions up to $10^{7} .100$ $\mu \mathrm{l}$ from last three dilutions was taken as an inoculum in the plate and melted nutrient agar (NA) media was poured in to it. Then the inoculated plates were incubated in an incubator at $37{ }^{\circ} \mathrm{C}$ for 24 hours. After collection of maximum number of diverse organisms, initial screening was performed for phosphate $(\mathrm{P})$ solubilization on Pikovskya medium and IAA production in LB broth with $0.1 \%$ tryptophan. The best phosphate solubilising bacteria (PSB) with ability to produce IAA was selected for further study.

\subsection{Morphological and Biochemical characterization}

Isolate was characterized for Gram staining, morphology and biochemical characters such as catalase, oxidase, and carbohydrates fermentation starch hydrolysis capability, catalase activity, Methyl red (MR), citrate utilization, phenyl alenine deaminase, Gelatin Hydrolysis, MR (Methyl Red), Triple Sugar Iron Agar (TSIA), Urease, Voges Proskauer (VP) etc. [11]. All incubations of the biochemical tests were done at $37^{\circ} \mathrm{C}$.

\subsection{Antibiotic Susceptibility test}

To evaluate the susceptibility of $K$ pneumoniae VRE36 to different antibiotics overnight grown $1 \mathrm{ml}$ of culture was inoculated into sterile $20 \mathrm{ml}$ melted nutrient agar and poured into sterile $9 \mathrm{Cm}$ Petri plates. After the media got solidified HiMedia hexa antibiotic disc were placed on the surface followed by overnight incubation at $37^{\circ} \mathrm{C}$ and clear zone of inhibition was recorded.

\subsection{Phosphate solubilization activity}

To determine the phosphate solubilization, Pikovskaya's agar [12] plates were spot inoculated with $K$ pneumoniae culture and incubated at $30^{\circ} \mathrm{C}$ for 4 days. Appearance of clear halos around bacterial colony indicated the phosphate solubilisation ability and solubization index was measured [13].

Phosphate solubilization index $=($ colony diameter + halo zone $) /$ colony diameter

Quantitative estimation of soluble phosphate in broth was carried out using Erlenmeyer flasks $(150 \mathrm{ml})$ containing $25 \mathrm{ml}$ of NBRIP medium which contained per litre: glucose - 10gm;
$\mathrm{MgCl}_{2} \cdot 6 \mathrm{H}_{2} \mathrm{O}$ - 5gm; $\mathrm{MgSO}_{4} .7 \mathrm{H}_{2} \mathrm{O}$ - 0.25gm; $\mathrm{KCl}$ - 0.2gm; $\left(\mathrm{NH}_{4}\right)_{2} \mathrm{SO}_{4}-0.1 \mathrm{gm}$. Autoclaved broth was inoculated in triplicate with the bacterial strain $\mathrm{K}$ pneumoniae and uninoculated medium served as control. The flasks were incubated for $96 \mathrm{~h}$ at $30^{\circ} \mathrm{C}$ on an incubator shaker at $180 \mathrm{rpm}$. The cultures were harvested by centrifugation at $8000 \mathrm{rpm}$ for $15 \mathrm{~min}$. Phosphorus in the cell free culture supernatant was determined. For this, $1 \mathrm{ml}$ of the supernatant was taken, $2.5 \mathrm{ml}$ of Barton's reagent was added and volume was made up to $50 \mathrm{ml}$ with distilled water. After 15 minutes, the intensity of yellow colour was read on spectrophotometer at $430 \mathrm{~nm}$ and the amount of $\mathrm{P}$ solubilised was extrapolated from the standard curve.

\subsection{Indole acetic acid (IAA) production}

Production of IAA by the $K$ pneumoniae was detected according to the modified method described by Bric [14]. Twenty four hour grown culture was inoculated into $10 \mathrm{ml}$ sterile LB amended with $0.1 \%$ tryptophan. After incubation at $37{ }^{\circ} \mathrm{C}$ for $96 \mathrm{~h}$ IAA produced was determined in culture supernatant $(1 \mathrm{ml})$ using Salkowski reagent $(2 \mathrm{ml})$ and the amount of IAA produced was extrapolated from the standard curve. Optical density was measured at $530 \mathrm{~nm}$ on spectrophotometer (Shimadzu).

\subsection{Seed germination assay}

$K$ pneumoniae VRE36 inocula was prepared by inoculation of single colony into nutrient broth and kept in an orbital shaker (150 rpm) for $24 \mathrm{~h}$. Culture was centrifuged in $15 \mathrm{ml}$ sterile plastic tubes at $6000 \mathrm{rpm}$ for $15 \mathrm{~min}$ and pellets were resuspended in sterile distilled water (SDW) to obtain a final concentration of $10^{8}$ colony forming units $(\mathrm{CFU} / \mathrm{ml})$. Seeds of Cluster bean, green gram and black eyed bean were sterilized by dipping in $2 \% \mathrm{NaOCl}$ solution for $10 \mathrm{~min}$ and then washed three times with SDW. Seeds were dipped into the inocula $\left(10^{8} \mathrm{CFU} / \mathrm{ml}\right)$ for $30 \mathrm{~min}$ and dried under laminar airflow condition and planted into the pot containing $1 \mathrm{~kg}$ four time autoclaved soil $(\mathrm{pH} 7.53, \mathrm{~N}$ $419.2 \mathrm{mg} / \mathrm{kg}, \mathrm{P}-8.26 \mathrm{mg} / \mathrm{kg}, \mathrm{K}-156.69 \mathrm{mg} / \mathrm{kg}$, Carbon - 0.69\%, EC- $4.38 \mathrm{ds} / \mathrm{m})$. Seed treated with SDW were served as control. Experiments were performed in a completely randomized block design and growth parameters were measured after 5 days.

\subsection{Molecular identification and phylogeny}

The genomic DNA was isolated according to Sambrook [15]. Amplification of 16S rRNA gene of BPR7 was carried out by PCR (Eppendorf) using universal eubacterial primer set 8F: 5'AGA GTT TGA TCM TGG CTC AG-3', 1492R: 5'- CGG TTA CCT TGT TAC GAC TT-3'. The total PCR reaction mixture was $50 \mu \mathrm{l}$ comprising $200 \mathrm{mM}$ dNTPs, 50mM each primer, 1X PCR buffer, 2U Taq polymerase, and 100ng genomic DNA. The thermocycling conditions involved an initial denaturation at $94{ }^{\circ} \mathrm{C}$ for $4 \mathrm{~min}$, followed by 35 cycles of $94{ }^{\circ} \mathrm{C}$ for $1 \mathrm{~min}, 52{ }^{\circ} \mathrm{C}$ for 1 $\mathrm{min}$, and $72{ }^{\circ} \mathrm{C}$ for $2 \mathrm{~min}$ and final extension at $72{ }^{\circ} \mathrm{C}$ for $8 \mathrm{~min}$. Forward and reverse DNA sequencing reaction of PCR amplicon was carried out with $8 \mathrm{~F}$ and 1492R primers using BDT v3.1 Cycle sequencing kit on ABI 3730xl Genetic Analyzer. Similarity of 16S 
rRNA gene sequence was aligned using BLAST programme of GenBank database (NCBI) and aligned to their nearest neighbours. The evolutionary distances among $K$ pneumoniae isolates and phylogenetic tree was constructed using MEGA 6.0 software and Kimura's two-parameter model, after aligning the sequences with ClustalW.

\section{RESULT AND DISCUSSION}

PGPR are free living soil bacteria that aggressively colonize the plant roots and when applied to the seeds or crops they enhance the growth and yield of the plant [16]. The presence study carried out to characterize the potential of sugarcane PGPR $K$ pneumoniae to support the growth of plants by its biochemical activity. In total 108 organisms were isolated on nutrient agar plate and on the basis of $\mathrm{P}$ solubilization activity and IAA production, strain VRE36 was selected for further work.

\subsection{Morphological and Biochemical characterization}

Morphological characterization of the isolate based on Gram test revealed that the bacterium was gram negative and rod shaped. Colony characters on Nutrient agar plate shows that isolate was non pigmented, fast growing, having small round shape colony with raised elevation and smooth surface.

It was observed that out of fifteen biochemical test performed, isolate shown positive results for ten tests. The biochemical analysis results are summarized in Table 2 .

\subsection{Antibiotic Susceptibility test}

$K$ pneumoniae VRE36 susceptibility was evaluated against 27 antibiotics and found to be sensitive against 22 antibiotics (Table 3). K pneumoniae was resistant to 5 antibiotics namely Ceftazidime, Linezolid, Cloxacillin, Lincomycin, and Cefuroxime.

\subsection{Phosphate solubilization activity}

Phosphorous is a second major nutrient after nitrogen require for plant growth. The bacteria with good ability to solubilise phosphate should have a good halo zone to colony ratio. This criterion is generally used for preliminary screening of phosphate-solubilising micro-organisms including fungi and bacteria. In present study the phosphate solubilization index of the isolate recorded was 3.9. The ratios for bacteria in this study were much higher than 1.17-2.96 for phosphate-solubilising fungi in asparagus root zone [17]. Islam et al. [18] reported the phosphate solubilization index of the rice isolates varied from 1.2 to 6.7. Many species of rhizobacteria including Bacilli, Pseudomonas and Klebsiella can solubilise insoluble phosphates in the agar assay in vitro [19-20]. Quantitative estimation in NBRIP broth reveals $17.4 \pm 1.78 \mu \mathrm{g} / \mathrm{ml}$ solubilised $\mathrm{P}$ (Table 1 ). This data is in accordance with the Henry et al reported $14.23 \mu \mathrm{g} / \mathrm{ml} \mathrm{P}$ solubilisation by HB3 strain [21]. Zahid et al reported the $\mathrm{P}$ solubilisation potential of $19.2 \mu \mathrm{g} / \mathrm{ml}$ and $35.6 \mu \mathrm{g} / \mathrm{ml}$ for Pseudomonas stutzeri and Bacillus subtilis respectively [22]. The activity of PSB is crucial for crop production under condition where $\mathrm{P}$ is a limiting factor.

Table 1: Details of Sugarcane Co99004 root rhizosphere isolate VRE36.

\begin{tabular}{|c|c|c|c|c|c|c|c|c|}
\hline $\begin{array}{c}\text { Isolate } \\
\text { code }\end{array}$ & identified by 16s rRNA & host cultivar & $\begin{array}{c}\text { place of } \\
\text { collection }\end{array}$ & homology & $\begin{array}{c}\text { Accession } \\
\text { number }\end{array}$ & $\begin{array}{c}\text { IAA production } \\
\mu \mathrm{g} / \mathrm{ml}\end{array}$ & $\begin{array}{c}\text { Phosphate } \\
\text { Solubilization Index } \\
\end{array}$ & $\begin{array}{c}\text { Phosphate solubilization } \\
\mu \mathrm{g} / \mathrm{ml}\end{array}$ \\
\hline VRE36 & Klebsiella pneumoniae & Co99004 & Bardoli & 91 & KX418655 & $45.32 \pm 2.46$ & 3.9 & $17.4 \pm 1.78$ \\
\hline
\end{tabular}

Table 2: Biochemical properties of Klebsiella pneumoniae VRE36.

$\begin{array}{cc}\text { Biochemical Test } & \text { Result } \\ \text { Glucose } & \text { Positive } \\ \text { Lactose } & \text { Positive } \\ \text { Maltose } & \text { Positive } \\ \text { Mannitol } & \text { Positive } \\ \text { Sucrose } & \text { Positive } \\ \text { Xylose } & \text { Positive } \\ \text { Phenylalanine Deaminase } & \text { Negative } \\ \text { Catalase } & \text { Positive } \\ \text { Citrate } & \text { Positive } \\ \text { Gelatin Hydrolysis } & \text { Negative } \\ \text { MR (Methyl Red) } & \text { Negative } \\ \text { Oxidase } & \text { Negative } \\ \text { TSIA (Triple Sugar Iron Agar) } & \text { Negative } \\ \text { Urease } & \text { Positive } \\ \text { VP (Voges Proskauer) } & \text { Positive }\end{array}$

Table 3: Antibiotic susceptibility of $K$ pneumoniae VRE36.

\begin{tabular}{|c|c|c|c|c|c|}
\hline Antibiotic Disk & $\begin{array}{c}\text { Zone of Inhibition } \\
(\mathrm{mm})\end{array}$ & Antibiotic Disk & $\begin{array}{c}\text { Zone of Inhibition } \\
\text { (mm) }\end{array}$ & Antibiotic Disk & $\begin{array}{c}\text { Zone of Inhibition } \\
(\mathrm{mm})\end{array}$ \\
\hline Ampicillin $10 \mu \mathrm{g}$ & 10 & Cefotaxime $30 \mu \mathrm{g}$ & 15 & Amoxyclav $30 \mu \mathrm{g}$ & 11 \\
\hline Ceftriaxone $30 \mu \mathrm{g}$ & 16 & Amikacin $30 \mu \mathrm{g}$ & 22 & Clarithromycin $30 \mu \mathrm{g}$ & 10 \\
\hline Chloramphenicol $30 \mu \mathrm{g}$ & 21 & Nitrofurantoin $300 \mu \mathrm{g}$ & 13 & Cloxacillin $1 \mu \mathrm{g}$ & $\mathrm{R}$ \\
\hline Ciprofloxacin $5 \mu \mathrm{g}$ & 27 & Netillin $30 \mu \mathrm{g}$ & 21 & Cephalothin $30 \mu \mathrm{g}$ & 10 \\
\hline Co-Trimoxazole $25 \mu \mathrm{g}$ & 14 & Nalidixic acid $30 \mu \mathrm{g}$ & 24 & Lincomycin $2 \mu \mathrm{g}$ & $\mathrm{R}$ \\
\hline Tetracycline $30 \mu \mathrm{g}$ & 25 & Vancomycin $30 \mu \mathrm{g}$ & 9 & Cefuroxime $30 \mu \mathrm{g}$ & $\mathrm{R}$ \\
\hline Cefpodoxime $10 \mu \mathrm{g}$ & 9 & Oxacillin $1 \mu \mathrm{g}$ & 17 & TobramycinM $10 \mu \mathrm{g}$ & 21 \\
\hline Clavulanic acid $5 \mu \mathrm{g}$ & 11 & Linezolid $30 \mu \mathrm{g}$ & $\mathrm{R}$ & Erythromycin $15 \mu \mathrm{g}$ & 28 \\
\hline Ceftazidime $30 \mu \mathrm{g}$ & $\mathrm{R}$ & Clindamycin $2 \mu \mathrm{g}$ & 10 & Gentamicin $10 \mu \mathrm{g}$ & 18 \\
\hline
\end{tabular}




\subsection{Indole acetic acid (IAA) production}

Interaction between microbes and plants is well studied for symbiotic mechanism in which plant releases amino acids, vitamins and other nutrients and microbes metabolize these substances to produce products which influence the growth of the plants. IAA is an acid hormone synthesize by microorganism by various known pathways which may be tryptophan dependent or independent [23]. In soil, the tryptophan may be available in the rhizosphere naturally through root exudates as reported by Beniziri et al [24]. In the present study LB medium was amended with $0.1 \%$ tryptophan which act as a precursor for the biosynthesis of IAA. The production of phytohormone IAA is considered as an effective tool for screening beneficial microorganisms as there have been reports suggesting that IAA producing bacteria have profound effect on plant growth [25]. In the presence of tryptophan, the amount of IAA produced was estimated from the standard and recorded $45.32 \pm 2.46 \mu \mathrm{g} / \mathrm{ml}$ after incubation at $37{ }^{\circ} \mathrm{C}$ for $96 \mathrm{~h}$ (Table 1). Colour development was first visible within minutes and continued to increase in intensity for a period of 30 min. Similar research report has been documented on Klebsiella species for phytohormone production from rhizosphere of sugarcane, soyabean and rice [25, 26-27]. IAA production for $K$ pneumoniae in present study was comparable to that reported by other authors for Klebsiella species K8 $(171.9 \mu \mathrm{g} / \mathrm{ml})$ and $\mathrm{K} 42$ $(11.12 \mu \mathrm{g} / \mathrm{ml})$ in chemically defined media [28].

\subsection{Seed germination assay}

The seeds are the reproductive part of the plant which is expected to give rise healthy plant. The oretically, application of
PGPR should promote shoot growth and root growth, and, therefore, plant height, fresh weight and dry weight of sterilized soil control should be higher than those of without treatment. In this study, application of $\mathrm{K}$ pneumoniae supported higher germination rate and other growth parameters (Figure1). Similar studies on Klebsiella strains for plant growth promoting traits on wheat plant under axenic conditions suggests that these are promising strains for application in agriculture [28]. In recent study, maximum percentage of germination (GP) was recorded in $V$ radiate $(97.78 \%)$.

The variations in plant (height, dry weight and fresh weight) among the control and treated seeds were significant (Table 4).

The increased rate of seed germination and seedling parameters in PGPR treated seeds as compare to uninoculated seeds may be due to the release of growth hormone IAA [29]. In case of $C$ tetragonoloba, plant heights increased from $12.10 \mathrm{~cm}$ (control) to 17.03 (treatment) were observed (Table 4). As with plant height, seed treatment also had the highest plant dry weight $(0.29 \mathrm{~g})$, which was not significantly different from control $(0.16$ g). Treated $V$ radiata seeds had shown the highest plant height $(23.43 \mathrm{~cm})$ as compared to control $(15.97 \mathrm{~cm})$. Similar observations were made in the case of growth parameters for $V$ unguiculata.

In all pot trial, treatments with bacteria were significantly higher than control. As the isolate in this study produced higher IAA and have phosphate solubilization activity, it might have directly or indirectly influenced the seed germination and plant growth.
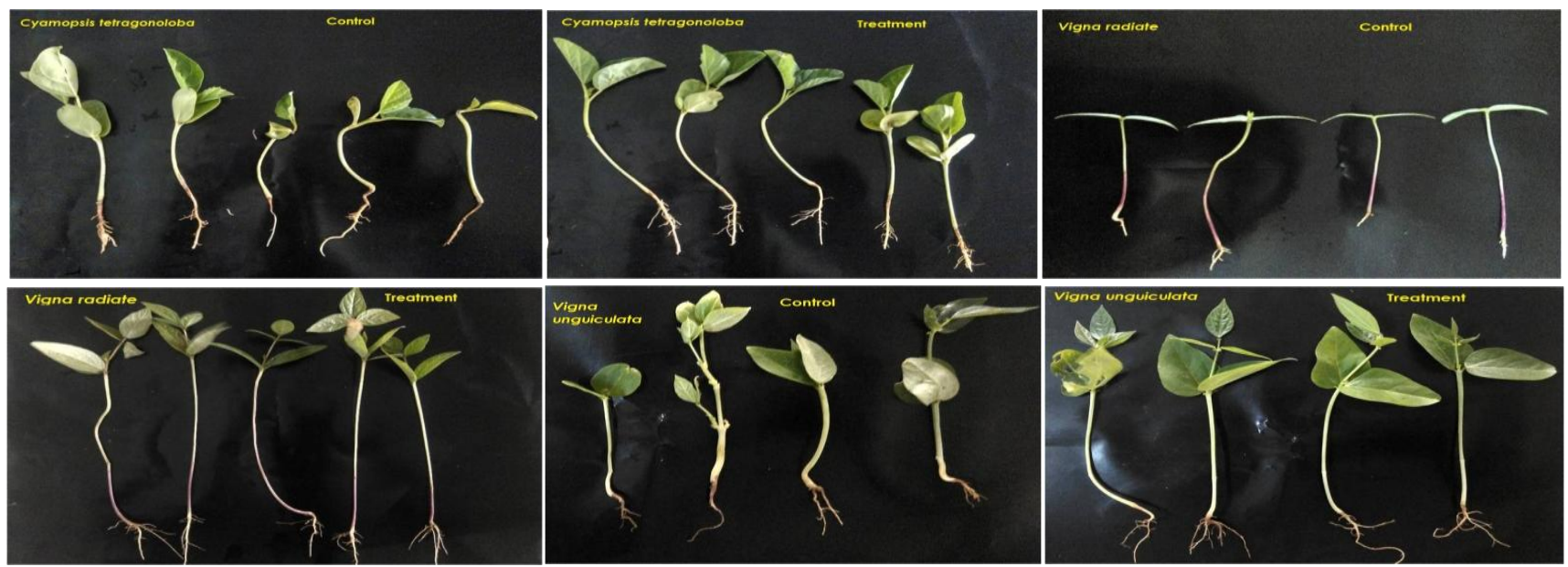

Fig. 1: Growth enhanced by K pneumoniae VRE36 in seed germination assay.

Table 4: Effects K pneumoniae VRE36 on plant growth parameters in seed germination assay. Data represents Mean ( $\mathrm{n}=10) \pm$ Standard Deviation. Germination percentage (GP), Plant Height (PH), Leaf width (LW), Leaf height (LH), Shoot Length (SL), Root length (RL), Fresh Weight of plant (FWP), Dry weight of plant (DWP).

\begin{tabular}{|c|c|c|c|c|c|c|c|c|c|}
\hline Seeds & & GP & PH(Cm) & LW $(\mathrm{Cm})$ & LH (Cm) & SL(Cm) & RL(Cm) & FWP(Gm) & DWP(Gm) \\
\hline \multirow{2}{*}{ C tetragonoloba } & Control & $79.44 \pm 8.22$ & $12.10 \pm 1.91$ & $2.03 \pm 0.35$ & $3.30 \pm 0.66$ & $3.97 \pm 0.55$ & $3.77 \pm 0.55$ & $0.56 \pm 0.06$ & $0.16 \pm 0.03$ \\
\hline & Treated & $93.89 \pm 2.55$ & $17.03 \pm 1.50$ & $3.23 \pm 0.23$ & $3.50 \pm 0.20$ & $8.17 \pm 0.96$ & $4.97 \pm 0.45$ & $0.84 \pm 0.11$ & $0.29 \pm 0.03$ \\
\hline \multirow{2}{*}{$V$ radiata } & Control & $65.56 \pm 8.55$ & $15.97 \pm 0.55$ & $1.36 \pm 0.15$ & $3.30 \pm 0.92$ & $10 \pm 1.10$ & $2.57 \pm 0.65$ & $0.25 \pm 0.03$ & $0.12 \pm 0.02$ \\
\hline & Treated & $97.78 \pm 2.55$ & $23.43 \pm 1.36$ & $1.59 \pm 0.19$ & $4.93 \pm 1.20$ & $16.20 \pm 0.95$ & $3.97 \pm 0.65$ & $0.54 \pm 0.08$ & $0.21 \pm 0.03$ \\
\hline \multirow{2}{*}{ V unguiculata } & Control & $75.56 \pm 7.52$ & $10.82 \pm 0.63$ & $2.07 \pm 0.21$ & $2.68 \pm 0.24$ & $6.16 \pm 0.19$ & $2.63 \pm 0.18$ & $0.94 \pm 0.02$ & $0.28 \pm 0.02$ \\
\hline & Treated & $96.11 \pm 0.96$ & $22.58 \pm 2.70$ & $3.52 \pm 0.09$ & $5.27 \pm 0.57$ & $10.34 \pm 0.60$ & $5.57 \pm 0.35$ & $1.41 \pm 0.20$ & $0.65 \pm 0.02$ \\
\hline
\end{tabular}




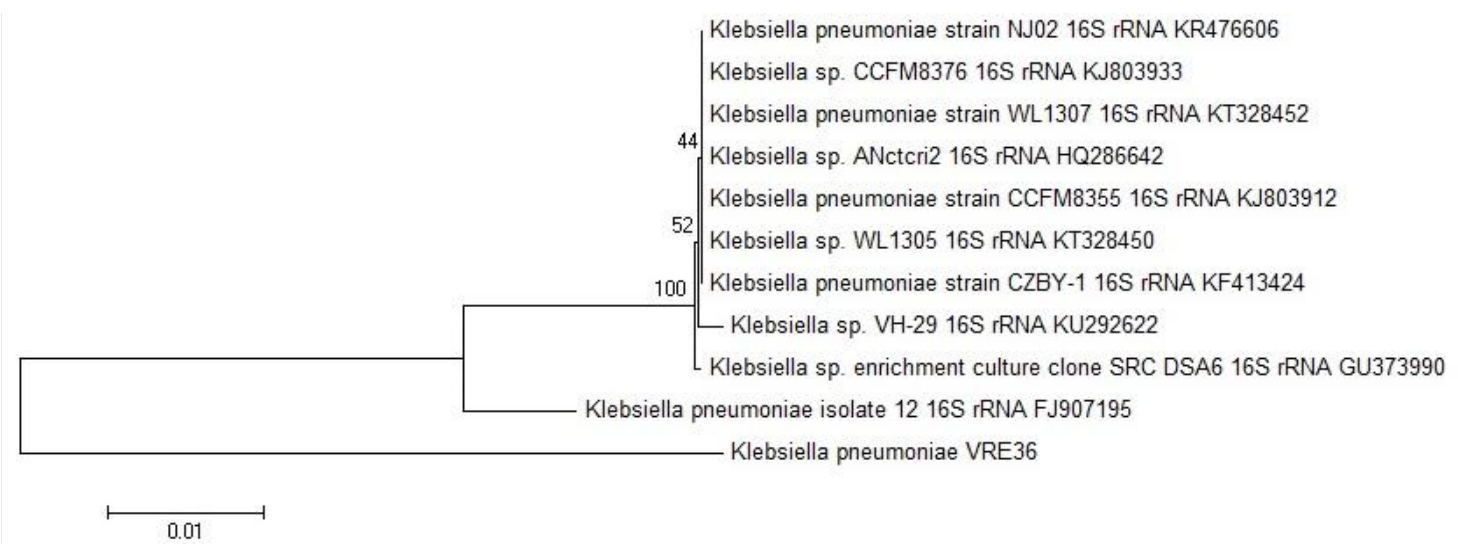

Fig. 2: A neighbor-joining tree derived from sequences of $16 \mathrm{~S}$ rRNA region. Numbers on nodes represent bootstrap values (\%) from 1000 replicates. A phylogenetic tree was constructed using MEGA 6.0 with kimura-two parameter model. Bar represents 0.01 substitutions per site.

\subsection{Molecular identification and phylogeny}

The isolate were later identified for their species using partial 16S rDNA sequencing method. BLAST results confirmed that the isolate homology was identical to $K$ pneumoniae isolate 12 with $91 \%$ of homology (FJ907195.1). The 16S rDNA gene sequences of $K$. pneumoniae VRE36 determined in this study were deposited in GenBank database (http://www.ncbi.nlm.nih.gov/GenBank/index.html) under accession number KX418655. The evolutionary history was inferred using the Neighbour-Joining method. The optimal tree with the sum of branch length 0.09827708 is shown (Figure 2). The percentage of replicate trees in which the associated taxa clustered together in the bootstrap test (1000 replicates) is shown next to the branches.

The tree is drawn to scale, with branch lengths in the same units as those of the evolutionary distances used to infer the phylogenetic tree. The evolutionary distances were computed using the Kimura 2-parameter method and are in the units of the number of base substitutions per site. The analysis involved 11 nucleotide sequences. All positions containing gaps and missing data were eliminated. There were a total of 1084 positions in the final dataset. Evolutionary analyses were conducted in MEGA 6.0. Phylogenetic tree of PSB Klebsiella strain VRE36 revealed that the strain is presented on separate clade, indicating that these strains of Klebsiella was of different phylotypes. Isolation source of Klebsiella strains selected NCBI to construct the tree was different form our isolate like Hami-melon juice (FJ907195), dental caries (GU373990), rhizosphere region of Rockwell plant (HQ286642) so that may be the reason for our sequence VRE36 does not fall in any cluster.

\section{CONCLUSION}

The research met our objective in identifying the bacteria from Co99004 as a most promising and worth exploring in further studies to develop bio-fertilizer with good ability to solubilise phosphate and production of phytohormone IAA. Although isolate $K$ pneumoniae supported good germination and plant growth tested, further investigations in details are also required to confirm their ability in field.

\section{Financial support and sponsorship: Nil.}

Conflict of Interests: There are no conflicts of interest.

\section{REFERENCES}

1. Bhattacharyya P, Jha D. Plant growth-promoting rhizobacteria (PGPR): emergence in agriculture. World Journal of Microbiology and Biotechnology. 2012; 28(4):1327-1350.

2. Qureshi MA, Ahmad ZA, Akhtar N, Iqbal A. Role of phosphate solubilizing bacteria (PSB) in enhancing P-availibility and promoting cotton growth. Journal of Animal-Plant Science. 2012; 22:204-210.

3. Vessey JK. Plant growth promoting rhizobacteria as biofertilizers. Plant and soil. 2003; 255(2):571-586.

4. Glick BR, Karaturovíc DM, Newell PC. A novel procedure for rapid isolation of plant growth promoting pseudomonads. Canadian Journal of Microbiology. 1995; 41(6):533-536.

5. Das AC, Mukherjee D. Influence of insecticides on microbial transformation of nitrogen and phosphorus in Typic Orchragualf soil. Journal of Agricultural and Food Chemistry. 2000; 48(8):3728-3732.

6. Kundu B, Gera R, Sharma N, Bhatia A, Sharma R. Host specificity of phosphate solubilizing bacteria. Indian Journal of Microbiology. 2002; 42(1):19-21.

7. Aris T. Wahyudi RIA. Screening of Pseudomonas sp. isolated from rhizosphere of soybean plant as plant growth promoter and biocontrol agent. American Journal of Agricultural and Biological Sciences. 2011; 6(1):134-141. doi: 10.3844/ajabssp.2011.134.141

8. Hafeez FY, Yasmin S, Ariani D, Zafar Y, Malik K. A. Plant growthpromoting bacteria as biofertilizer. Agronomy for Sustainable Development. 2006; 26(2):143-150.

9. Jorquera MA, Hernández MT, Rengel Z, Marschner P, Mora M. Isolation of culturable phosphobacteria with both phytatemineralization and phosphate-solubilization activity from the rhizosphere of plants grown in a volcanic soil. Biology and Fertility of Soils. 2008; 44(8):1025-1034.

10. Rodriguez H, Gonzalez T, Selman G. Expression of a mineral phosphate solubilizing gene from Erwinia herbicola in two rhizobacterial strains. Journal of Biotechnology. 2000; 84(2):155-161.

11. Cappuccino JGS, Cappuccino NJG, Sherman N. Microbiology: a laboratory manual. 1996.

12. Pikovaskaya RI. Mobilization of phosphorous in soil in connection with the vital activity of some microbial species. Microbiologia. 1948; 17:362-370. 
13. Premono ME, Moawad A, Vlek P. Effect of phosphate-solubilizing Pseudomonas putida on the growth of maize and its survival in the rhizosphere. Indonesian Journal of Crop Science. 1996; 11:13-23.

14. Bric JM., Bostock RM, Silverstone SE. Rapid in situ assay for indoleacetic acid production by bacteria immobilized on a nitrocellulose membrane. Applied and Environmental Microbiology. 1991; 57(2):535-538.

15. Sambrook J, Russell DW. Molecular cloning: a laboratory manual 3rd edition. Coldspring-Harbour Laboratory Press, UK. 2001.

16. Kumar A, Maurya BR, Raghuwanshi R. Isolation and characterization of PGPR and their effect on growth, yield and nutrient content in wheat (Treaticum aestivum L.). Biocatalyst Agriculture and Biotechnology. 2014; 3:121-128.

17. Ruangsanka S. Identification of phosphate-solubilizing fungi from the asparagus rhizosphere as antagonists of the root and crown rot pathogen Fusarium oxysporum. ScienceAsia. 2014; 40:16-20.

18. Islam M, Deora A, Hashidoko Y, Rahman A, Ito T, Tahara S. Isolation and identification of potential phosphate solubilizing bacteria from the rhizoplane of Oryza sativa L. cv. BR29 of Bangladesh. Zeitschrift für Naturforschung C. 2007; 62(1-2):103-110.

19. Ogbo F, Okonkwo J. Some characteristics of a plant growth promoting Enterobacter $s p$. isolated from the roots of maize. Advances in Microbiology. 2012; 2(3):368-374.

20. Widawati S, Suliasih HL, Sugiharto A. Biodiversity of Soil Microbes from Rhizosphere at Wamena Biological Garden (WBiG), Jayawijaya, Papua. Biodiversitas. 2005; 6(1):6-11.

21. Henry K, Baharuddin, Bandron Z, Syatrianty AS. Isolation and physiological characterization of PGPR from potato plant rhizosphere in medium land of Buru Island. Procedia Food Science. 2015; 3:190199.

22. Zahid M, Abbasi MK, Hameed S, Rahim N. Isolation and identification of indegenous plant growth prmoting rhizobacteria from himalayan region of kashmir and their effect on improving growth and nutrient contents of maize (Zea mais L.). Frontiers in Microbiology. 2015; 6(207). Doi: 10.3389/fmicb.2015.002017

23. Duca D, Lorv J, Patten CL, Rose D, Glick BR. Indole-3-acetic acid in plant microbe interactions. Antonie Van Leeuwenhoek.

24. Benizir E, Caurtade A, Picard C, Guckert A. Role of maize root exudates in the production of auxins by Pseudomonas flauroscens. Soil Biology and Biochemistry. 1998; 30:1481-1484.
25. Govindarajan M, Kwon SW, Weon HY. Isolation, molecular characterization and growth-promoting activities of endophytic sugarcane diazotroph Klebsiella sp. GR9. World Journal of Microbiology and Biotechnology. 2007; 23(7):997-1006.

26. El-Khawas H, Adachi K. Identification and quantification of auxins in culture media of Azospirillum and Klebsiella and their effect on rice roots. Biology and Fertility of Soils. 1999; 28(4):377-381.

27. Sobral J, Araújo WL, Mendes R, Geraldi IO, Kleiner AA, Azevedo JL. Isolation and characterization of soybean-associated bacteria and their potential for plant growth promotion. Environmental Microbiology. 2004; 6(12):1244-1251.

28. Sachdev DP, Chaudhari HG, Kasture VM, Dhavale DD, Chopade BA. Isolation and characterization of indole acetic acid (IAA) producing Klebsiella pneumoniae strains from rhizosphere of wheat (Triticum aestivum) and their effect on plant growth. Indian Journal of Experimental Biology. 2009; 47(12):993.

29. Hayat R, Ali S, Amara U, Khalid R, Ahmed I. Soil benificial bacteria and their role in plant growth promotion: a review. Annals of Microbiology. 2010; 60:579-598.

\section{How to cite this article:}

Bhardwaj G, Shah R, Joshi B, Patel P. Klebsiella pneumoniae VRE36 as a PGPR isolated from Saccharum officinarum cultivar Co99004. J App Biol Biotech. 2017; 5 (01): 047-052. DOI: $10.7324 / \mathrm{JABB} .2017 .50108$ 